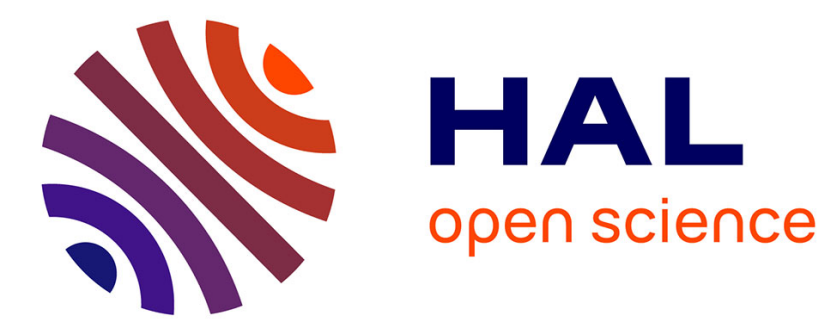

\title{
Innovation for development and poverty reduction: an integrative literature review
}

\author{
Mario Pansera, Fabien Martinez
}

\section{To cite this version:}

Mario Pansera, Fabien Martinez. Innovation for development and poverty reduction: an integrative literature review. Journal of Management Development, 2017, 36 (1), pp.2-13. 10.1108/JMD-022015-0013 . hal-02887777

\section{HAL Id: hal-02887777 https://hal.science/hal-02887777}

Submitted on 9 Jul 2020

HAL is a multi-disciplinary open access archive for the deposit and dissemination of scientific research documents, whether they are published or not. The documents may come from teaching and research institutions in France or abroad, or from public or private research centers.
L'archive ouverte pluridisciplinaire HAL, est destinée au dépôt et à la diffusion de documents scientifiques de niveau recherche, publiés ou non, émanant des établissements d'enseignement et de recherche français ou étrangers, des laboratoires publics ou privés. 


\title{
Innovation for development and poverty reduction: an integrative literature review*
}

\begin{abstract}
Purpose

This paper develops a critical analysis of the innovation discourse, arguing that a more contextualised understanding of the challenges of innovation for development and poverty reduction in low income economies will help us to unravel new development opportunities and provide alternatives to conventional capitalist paths to innovation.

\section{Design/methodology/approach}

We offer an integrative review of the literatures addressing the emerging topic of innovation emerging from within developing countries. Because existing innovation models are generally presented in ways that reflect practices and thought patterns inherent to the industrialised world, a literature review that offers an initial conceptualisation and synthesis of the literature to date on the theme of innovation from within developing countries provides for a more valuable contribution than a reconceptualization of existing models.
\end{abstract}

\section{Findings}

The article highlights different narratives of innovation, how they emerge and what are their implications. We outline a research agenda for generating new knowledge about innovation capabilities in what is generally known as the developing world.

\section{Originality/value}

This article shows that the recent evolution of the discourse of development is increasingly intertwined with elements that originated in other discursive worlds. The last three decades of innovation research have been characterised by a 'cross-pollination' between different disciplines: development studies, science and technology studies (STS), business management and organization studies. By reviewing major research works conducted by scholars in these disciplines, this article weds literatures that heretofore have remained largely isolated from each other. The key innovation narratives that the study unveils - e.g. inclusive growth, BOP, grassroots innovation - address major questions of concern to these academic scholars around the political and sociotechnical aspects that influence a firm's capacity to innovate in the context of developing countries.

Keywords: innovation, development, emerging economies, sustainability, literature review.

\section{Introduction - The challenge of innovation for development}

This paper develops a critical analysis of the innovation discourse, arguing that a more contextualised understanding of the challenges of innovation for development and poverty reduction in low income economies will help us to unravel new development opportunities and provide alternatives to conventional capitalist paths to innovation. There is no shortage of scholarship arguing that innovation stemming from scientific and

*Postprint of: Pansera, M., \& Martinez, F. (2017). Innovation for development and poverty reduction: an integrative literature review. Journal of Management Development, 36(1), 2-13. 
technological excellence, and often driven by firms, is critical to the sustainable development of our societies (Freeman, 2002; Freeman \& Soete, 1997; Ahlstrom, $2010)^{1}$. As our understanding of economic, environmental and social sustainability challenges becomes sharper, discourses of sustainability management scholars who use the term 'innovation' evolved to consider the multiplicity of micro-, meso- and macrolevel domains where innovative practices are, or ought to be, developed. Business research on the theme of innovating for sustainability has become a consistent stream. Research groups focusing on this topic have been created and new thematic journals have emerged ${ }^{2}$ (Fagerberg \& Verspagen, 2009). The bulk of this literature has tended to focus on innovation practices in the context of industrialised countries in North America, Europe and Japan (Wyld and Maurin, 2009) ${ }^{3}$. In this literature, hope for change is still mainly embodied in the idea of scientific and technological progress. Science and technology are argued to lay the foundations for widespread wellbeing at the beginning of the twentieth century, and there is no conspicuous reason to think that they will not deliver increasing benefits in the future (Ahlstrom, 2010). The whole modern industrial system is seen to be engaged in a never ending race to provide more efficient technologies, more appealing products and services. Innovation research seeks to understand how this process occurs, how it can be improved and hastened to deliver economic growth and, thus, wealth in any country. Research results and emerging concepts are sometimes leveraged to suggest how companies can use (scientific, technical and technological) innovations to compete in the global economy, making more or less explicit inferences to innovation practices in the context of developing countries (Guillén and García-Canal, 2009) ${ }^{4}$.

However, the features of socio-technical innovation and development that prevail in the standardised setting of industrialised countries can become fuzzy and elusive in the context of less developed regions, where exacerbated social and environmental problems call for a better alignment of our innovation models. Perhaps a shift from traditional views of innovation, development and modernity that essentially rely on scientific and technological progress catalysed by the wealthiest towards a recognition of political, cultural and cognitive factors that drive innovation in low income economies will help us to foster realignment. Sahlins $(1992,1993)$ explains that the modernising

\footnotetext{
${ }^{1}$ Ahlstrom, D. (2010). Innovation and Growth: How Business Contributes to Society. The Academy of Management Perspectives, 24(3), 11-24.

2 Can you attach example of those here ?

${ }^{3}$ Wyld, D. C., \& Maurin, R. (2009). Keys to Innovation: The Right Measures and the Right Culture? The Academy of Management Perspectives, 23(2), 96-98. doi: 10.5465/amp.2009.39985544

${ }^{4}$ Guillén, M. F., \& García-Canal, E. (2009). The American Model of the Multinational Firm and the "New" Multinationals From Emerging Economies. The Academy of Management Perspectives, 23(2), 23-35. doi: 10.5465/amp.2009.39985538
} 
wave of capitalism does not sweep away traditional cultures. Instead it triggers unexpected pathways of change for the individual subjects who strive to make sense of a new condition. A number of studies in the field of political ecology document how indigenous communities strive to preserve their traditions and customs and oppose the modern capitalist tendency of commodifying natural resources via social and technical rearrangements (Joan Martinez-Alier, 2002). Innovation in this scenario hardly fits the traditional label of a 'creative process of novelty'. It contests the very teleology of innovation by supporting the idea that innovation underpins a purpose, a goal that is not just novelty for the sake of novelty (or for the sake of profit). We posit that the purpose that leads us to innovate and change our social lives or the tools we use in our daily lives is not exclusively linked to the progress of science and technology but also to the fundamental political questions: why do we want to change? Why do we need to change? How are we going to change? Who will win or lose after the change? From this perspective, one might argue that industrial actors can learn valuable knowledge from their operations, partners, and/or acquired firms in developing countries where cases of socio-technical changes and innovations driven by political, cultural and cognitive factors are numerous and diverse, yet understudied in innovation research (Hitt, 2005) 5 .

In this article, we offer an integrative review of the literatures addressing the emerging topic of innovation emerging from within developing countries. Because existing innovation models are generally presented in ways that reflect practices and thought patterns inherent to the industrialised world, a literature review that offers an initial conceptualisation and synthesis of the literature to date on the theme of innovation from within developing countries provides for a more valuable contribution than a reconceptualization of existing models. The last three decades of innovation research have been characterised by a 'cross-pollination' between different disciplines: development studies, science and technology studies (STS), business management and organization studies. By reviewing major research works conducted by scholars in these disciplines, this article weds literatures that heretofore have remained largely isolated from each other. The key innovation narratives that the study unveils - e.g. inclusive growth, BOP, grassroots innovation - address major questions of concern to these academic scholars around the political and socio-technical aspects that influence a firm's capacity to innovate in the context of low income economies.

The paper is organised in four sections. We first introduce the reasons why contemporary studies of socio-technical change in the 'developing world' are more influential than ever. We then indulge in the new turn of innovation studies that focuses on the notions of

\footnotetext{
${ }^{5}$ Hitt, M. A. (2005). Management Theory and Research: Potential Contribution to Public Policy and Public Organizations. Academy of Management Journal, 48(6), 963-966. doi: 10.5465/amj.2005.19573098
} 
'innovation for the poor' and 'innovation from the poor'. The second section explains the selection of literature sources. The third section maps the narratives of innovation for development identified in the extant literature. Finally, we critically discuss these narratives and suggest directions for further research in this area.

\section{The new turn of innovation studies: heterodox modes of innovation under the radar}

How innovation emerges and diffuses from within the developing world is under represented in the academic literature (Lundvall, Vang, \& Chaminade, 2009). Nevertheless, the extant literature presents at least two major trends: those scholars interested in the process of 'catching-up' with advanced industrial countries through technology transfer and absorption e.g., (Fu, Pietrobelli, \& Soete, 2011; Kim, 1980); those focused on building up innovation systems i.e., the institutional and infrastructural environments that are supposed to make innovation flourish e.g., (Arocena \& Sutz, 2000; Cassiolato et al., 2003; Lundvall, Vang, \& Chaminade, 2009; Lundvall, Vang, Joseph, \& Chaminade, 2009; Muchie \& Gammeltoft, 2003). There is, however, a third group of scholars interested in 'pro-poor' and 'from the poor' innovation (Gupta, 2012; J. Hall, Matos, Sheehan, \& Silvestre, 2012). This last group intersects with development practices at micro level on the field - e.g. the work of NGOs, social movements and activists - reason for which in this article we will focus only this last trend.

At the end of the decade of the 1990s the topics of development and poverty, once dominated by development economists, had gone largely under the radar of management, organization and innovation scholars (Kolk, Rivera-Santos, \& Rufin, 2013; Pansera \& Owen, 2014; Pansera, 2013). Intriguing and provocative concepts such as 'frugal innovation' (Bound \& Thornton, 2012), 'reverse innovation' (Govindarajan \& Trimble, 2012), 'Jugaad innovation' (Radjou, Prabhu, Ahuja, \& Roberts, 2012), 'BOP' innovation' (Prahalad, 2010, 2012), 'Gandhian innovation' (Prahalad \& Mashelkar, 2010), 'empathetic innovation' and 'pro-poor vs. from-the-poor' (Gupta, 2010a, 2012), 'long tail and long tailoring' innovation (Anderson \& Markides, 2007), 'below-the-radar innovation' (Kaplinsky, 2011) and 'inclusive innovation' (George et al., 2012) have begun to appear in the work of innovation business and organization scholars. These forms of innovation are characterised by conditions of material, financial, and human resource scarcity (Baker \& Nelson, 2005; Gibbert, Hoegl, and Valikangas, 2006; Keupp \&

\footnotetext{
${ }^{6}$ The notion 'Bottom of the Pyramid (BOP)' is usually indicates those living on less than 2 US dollars a month (Prahalad, 2010).
} 
Gassmann, 2013), resource insecurity and concerns regarding environmental sustainability (Sharma \& lyer, 2012). Their focus has been in general centred within the context of developing countries and specifically: their role in the global value chain (Kaplinsky, 2000), their potential as unexploited markets (Prahalad, 2010) and the emergence of indigenous forms of innovation (Smith, Fressoli, \& Thomas, 2014). All those perspectives agree on the fact that the innovation capacity -whatever this means - veiled or unveiled of a country must be enhanced in order to enter the club of developed countries.

This variegated literature aim at addressing three major questions: first, does innovation occur (and if so how) in resource-constrained environments in the global south (Keupp \& Gassmann, 2013). Second, how does innovation contribute to social inclusion and poverty alleviation (George et al., 2012; J. Hall et al., 2012; Halme, Lindeman, \& Linna, 2012), whereas delivering at the same time financially sustainable solutions? Third, what are the implications for the global world (Brown, 2005)? And in turn what are the implications for emerging innovation policy?

As regards the first question, there is a common agreement on the fact that organizations enable innovation by 'making do with what is at hand' (Baker \& Nelson, 2005; Garud \& Karnøe, 2003). Other studies also identify within the bounded creativity of teams the inception of Resource Constrained Innovation (RCI) (Hoegl, Gibbert, \& Mazursky, 2008). All stress the fact that frugality-driven innovations have the potential to deliver affordable and robust solutions for the poor (Bound \& Thornton, 2012).

Although second question has also been only partially explored, the extant literature present a plurality of terms, goals, purposes and motivations (Altenburg, 2009). Innovation scholars in both emerging and developing countries have, for example, called for actions to set up functional innovation systems to tackle directly via public intervention the issues of underdevelopment and poverty (Arocena \& Sutz, 2000; B. Lundvall, Vang, \& Chaminade, 2009; Martins Lastres \& Cassiolato, 2008; Muchie \& Gammeltoft, 2003). Others have stressed how innovation can in fact be the very cause of inequality and social exclusion (Arocena \& Senker, 2003; Arocena \& Sutz, 2003; Cozzens \& Kaplinsky, 2009; Cozzens, 2007, 2008). Entrepreneurship and organization scholars publishing in the so-called 'BOP literature' (Prahalad, 2010) offer a differing perspective. This literature, increasingly popular among organization and management scholars, focuses on the search for opportunities for companies that are interested in opening markets at the BOP through the development of 'good-enough' and affordable products (London, 2009; Prahalad \& Mashelkar, 2010). These scholars hypothesise that the BOP could be a source of breakthrough innovations (Prahalad, 2012) and a huge potential market for 
multinational corporations (London \& Hart, 2004; London, 2009). In contrast again, a more recent perspective suggests that innovation in the developing world is largely carried out in informal settings by grassroots movements that arise in reaction to social injustices and environmental problems, which are perceived as being caused by freemarket ideology (Smith et al., 2014). This perspective calls for patterns of innovation and development that are appropriate for the poor in the developing world (Abrol, 2005; Dagnino, 2009; Gupta et al., 2003).

Finally as regards the third question, there are increasing signals regarding the potential for and real impact of new innovation models coming from the Global South. The Nation Health Service (NHS) in the UK, for instance, is already looking at Indian innovations in healthcare to provide affordable services, guaranteeing at the same time high quality standards (NHS, 2013). Hart $(2002 ; 2011)$ has suggested that a new wave of 'green disrupting innovations' is about to flood the North. Brown (2005) warns against the blowback effects of Southern innovations on the North's competitiveness while Govindarajan and Trimble (2012) praise the advantages that 'reverse innovation' will bring to emergent economies like India and China.

\section{Methods: selection and classification of literature}

\section{sources}

In order to explore the evolution of the extant academic literature and identify notable emerging discourses linking innovation and development we carried out two keywords searches in Scopus and Web of Knowledge. Based on the above reasoning, for the database queries, 12 keywords were selected: "frugal innovation", "bottom of the pyramid", "bottom of the pyramid innovation", "inclusive innovation", "jugaad", "gandhian innovation", "pro-poor innovation", "below the radar innovation", "resource constrained innovation", "Inclusive growth", "inclusive development", "grassroots innovation". The bibliometrics analysis shows that the first paper appeared in 2005 and that the literature production exhibited a strong increase from 2010. From the two keywords searches we gathered a database of 218 papers. we complemented the database with a few strictly selected reports, newspaper articles or books that we think are highly relevant to understand where the academic community is directed as regards those topics, like grassroots innovation or non-mainstream economics for example, in which the peerreview literature is still scarce.

In order to understand the proliferation and use of the above mentioned concepts within the academic community, we then performed a network analysis with the help of the free 
open-source software Gephi7. Gephi is an interactive visualization platform that allows the analysis of complex networks and complex systems. We used the database to create a network of keywords and their relations (Figure 1). Each node of the network represents a keyword and each link between 2 nodes indicates that the 2 keywords appear in the same paper. The thickness of the link is proportional to the number of times the 2 keywords appear in the same paper. In order to make the visualization of 517 keywords possible, we grouped the keywords in macro groups. For example, we grouped all the keywords related to the concept of inclusion in the macro group 'Inclusive growth', and all the possible formulations of 'Bottom of the pyramid' in the macro group BOP. Finally, we applied a Louvain algorithm to discover the communities' structure of my network. The algorithm is designed to detect 'big aggregators' i.e., those nodes that are more connected than the others (Blondel et al., 2008). The algorithm detected four major communities: Inclusive growth, BOP, (Resource - constrained Innovation and Sustainability. Surprisingly enough, the keyword sustainability was not initially included in the 12 original keywords. A more accurate manual analysis reveals that in each community there are at least a couple of sub-communities. The dominant aggregate is grouped around the concept of 'inclusive growth' that contains the concepts of inclusive development, growth and social inclusion. Related to this concept we find two subgroups. One is composed of the literature that deals with the use of traditional knowledge in development, the other deals with the topic of inequality. The second dominant aggregate is the BOP. The community is situated between the concepts of inclusivity and innovation. Particularly important seems to be the presence of a sub-community of scholars that focus on microfinance. A relevant concept related to the BOP is also ICT technology, especially mobile technology. The third community in size is composed of two major aggregates: sustainability and grassroots. Particularly interesting is the presence of a sub-community focused on non-mainstream economics that publishes on topics such as 'de-growth and new economics'. Finally there is the community of innovation that contains concepts like 'frugal innovation, reverse innovation or affordable innovation'. Within this community there is a sub-community that focuses on legislative issues. A quite distinct and relevant sub-community within the innovation community is the 'India' community. This contains concepts like 'Jugaad, poor consumers' and fancy words like 'Indovation or Hindolence'.

In the following sections we describe in detail the four macro-communities that emerge from the network analysis: (resource-constrained) innovation $(\mathrm{RCI})$, BOP, grassroots innovation and the notion of Inclusive growth.

\footnotetext{
${ }^{7}$ Gephi is freely available at: https://gephi.org/
} 



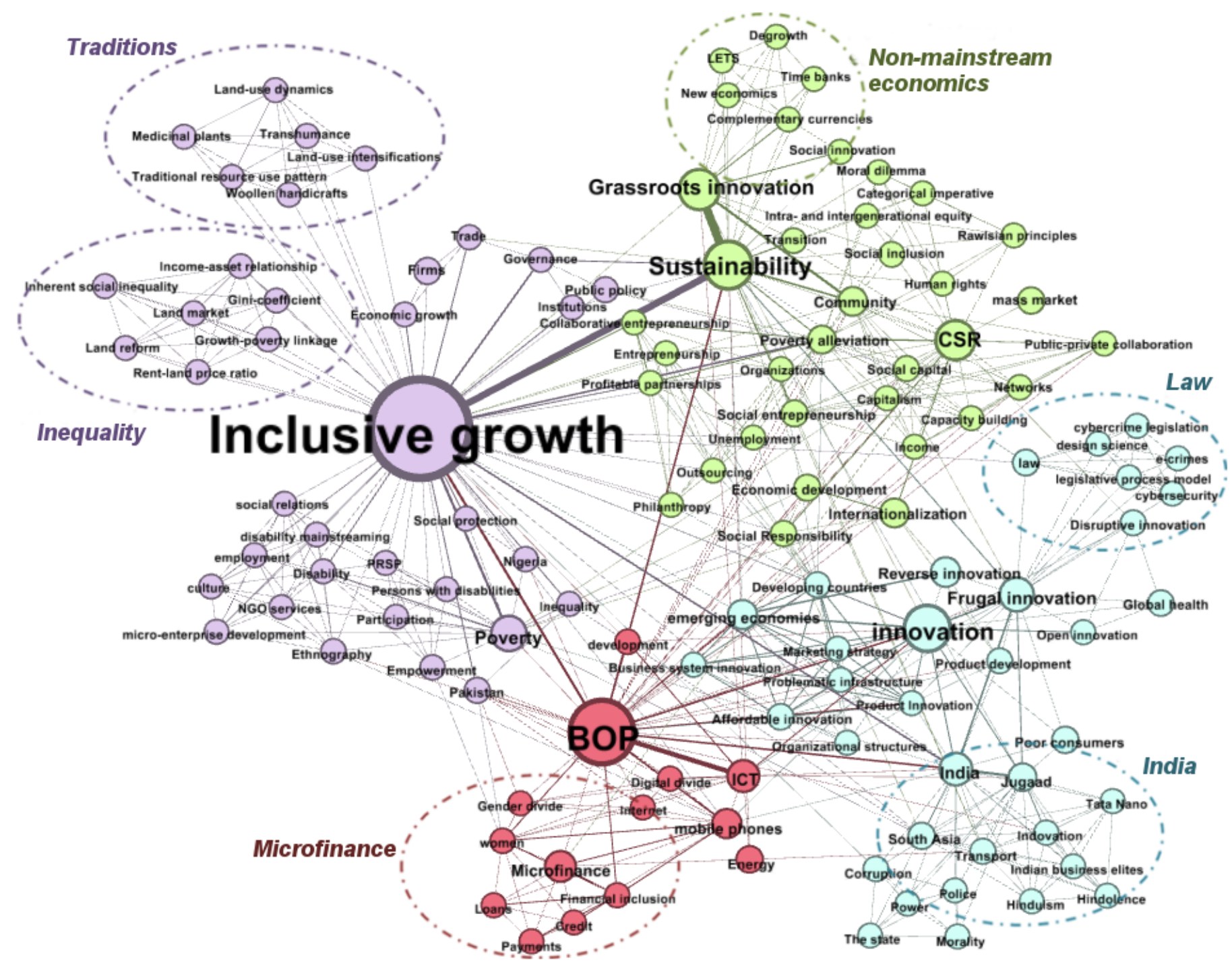

Figure 1 Systematic literature review network analysis 


\section{Findings: Narratives of innovation for development}

\section{Resource-Constrained Innovation (RCl): Bricolage, Frugality and Jugaad}

'Necessity is the mother of invention'. This popular phrase suggests that the necessity to address compelling needs sharpens ingenuity and encourages innovative thinking. Poverty, defined as a lack of material resources, and scarcity are certainly related. However, scarcity can also refer more generally to a situation of shortage of financial/materials resources or managerial skills in an organization. A recent business and management focused literature has approached the topic by introducing such concepts as $\mathrm{RCI}$, bricolage, frugality or Jugaad (Horn \& Brem, 2013).

An attempt to theorise $\mathrm{RCl}$, or 'scarcity-induced innovation', lies in the work of Srinivas and Sutz (2008). They argue that in the academic literature there has been a misguiding quest for innovation uniformity (i.e. the idea that the conditions needed to innovate are the same in any given context) that has sidelined the study of the capabilities needed to innovate in conditions of scarcity. The mainstream of innovation studies focuses on those innovations that occur in efficient innovation systems, while $\mathrm{RCI}$ usually takes place in a huge variety of different contexts and cannot be analysed using the same intellectual arsenal. Even more importantly, the innovation process in resource-constrained environments is not necessarily an earlier stage or the precursor of a fully-fledged innovation system. In their words:

'We argue that roughly speaking, people search for and design solutions within "technological universes". To innovate or to solve problems in a technological universe characterized by scarcity requires the development of a series of skills-learnt by doing, by searching, by interacting, by solving-that are idiosyncratic: we term them capacities to innovate in scarcity conditions' (Ibid.: 135).

A more organization-centred approach is presented in the bricolage literature. The notion of bricolage introduced by the anthropologist Levy-Strauss has been recently rediscovered to describe the condition of resources scarcity within organizations. According to Levy-Strauss, the bricoleur "is [...] someone who works with his hands and uses devious means compared to that of the craftsman [...] is adept at performing a large number of diverse tasks" (LéviStrauss, 1966, pp 16-18). The concept was introduced in the business literature at the beginning of the $21^{\text {st }}$ century by Baker et al. (2003) and Garud \& Karnøe (2003). The bricoleur firms "refuse to conceive scarcity as a limit" (Baker \& Nelson, 2005) and develop a number of strategies to cope with it. According to those authors, resource scarcity drives the development 
of capacities in firms to improvise and generate alternative solutions. The evidence from a number of empirical studies supports this assumption (Weiss, Hoegl, \& Gibbert, 2011). Another interesting effect of bricolage is the search for new applications of pre-existing technologies and/or solutions and the recombinant dynamics that this process generates. One of the characteristics of the bricoleur, indeed, is to combine different technologies that were originally designed for other purposes (Ibid). Given the resource limits that affect the BOP contexts, some authors have attempted to use the notion of bricolage to theorise how firms and organizations deal with scarcity at the BOP (Di Domenico et al., 2010; Gibbert et al., 2006; Halme et al., 2012; Immelt et al., 2009; Zeschky et al., 2011).

A number of examples document the bricolage activity of MNCs in emerging countries such as India and China (Immelt et al., 2009; Prathap, 2014). In this body of literature the concept of bricolage is usually replaced by the concept of frugality (Bhatti, 2013). Bricolage and frugality have vernacular equivalents in many languages. In India, for instance, frugal innovations are indicated by the Hindi world 'Jugaad'. Jugaad colloquially means a creative idea or a quick workaround to get through commercial, logistic or law issues (Radjou et al., 2012; Sharma \& lyer, 2012). The word gambiarra in Brazil and chapuza in Spain indicate shoddy work carried out with minimal means. The terms zizhu, chuangxin or shanzai in China indicate the low-cost counterfeiting manufacturing. Solution D in France, jua kali in Africa, DIY in the US and the art of arrangiarsi in Italian, all indicate bricolage attitudes. Those solutions share some very basic features (Rao, 2013) : They must be i) robust to deal with infrastructure shortcomings such as voltage fluctuation; ii) fault resistant to cope with unsophisticated or even illiterate users; iii) affordable for larger sections of the society.

A recent book by Radjou et al. (2012), explores in a journalistic fashion the extension of the jugaad attitude in India. According to the authors, not only is jugaad innovation a revolutionary tool in emerging countries, but it represents an unexpected opportunity for Western companies that are facing low rates of growth in the over-saturated markets of developed nations. By analysing the evidence coming from the field, other authors stress the fact that the 'jugaad attitude' is an indispensable element for firms and consumers survival in rural India (Singh, Gupta, \& Mondal, 2012). Some evidence suggests that MNCs are particularly interested in those dynamics for three reasons: to reduce the costs of products/service design, to create new markets in developing countries for low-cost products, and to explore the markets for disruptive innovations based on high-quality/low-cost products in wealthier nations. Two paradigmatic examples in this sense are the portable ECG machine for rural India and the ultrasound device for rural China, both developed by GE. When GE's portable ECG was redesigned by its Indian branch, the cost shrank from $\$ 10,000$ to $\$ 1,000$, whilst the Chinese 
were able to reduce the cost of the ultrasound device from $\$ 30,000$ to $\$ 10,000$. Those achievements have been made possible by rethinking the way GE used to design its products (Immelt et al., 2009). The local branch used low cost materials, less plastic and smaller LCD screens. They preferred local engineers, redesigning the software to reduce the memory requirement and using the same printer as that used in bus terminal kiosks in India (Kriplani, 2008). But maybe even more importantly, those pioneering machines are now being sold in the United States. This process is known as 'reverse innovation' and is quite the opposite of the technology transfer that characterised the early globalisation dynamics (Agarwal \& Brem, 2012; Govindarajan \& Trimble, 2012).

Some critical voices in the academia have questioned the positive framing of frugal/jugaad innovation. According to Birtchnell (2011: 249), for instance, 'Jugaad is a product of widespread poverty and underpins path dependencies stemming from dilapidated infrastructure, unsafe transport practices, and resource constraints. These factors make it wholly unsuitable both as a development tool and as a business asset'. The analysis of Krishnan (2010) of the Indian innovation potential published in the book 'From Jugaad to Systematic Innovation: The Challenge for India', stresses the temporary, precarious and uncertain consequences of a jugaad culture. According to Krishan, in fact, a modern country that aspires to become a world leading power should invest to build up a proper innovation system with the aim of triggering a systematic and continuous process of technological development, instead of indulging in notions like frugality and jugaad. He thinks this is produced by what he calls Hindolence, which he describes as a 'bhraminical attitude', 'lack of a strong time orientation', 'disdain for physical work', and being 'passive on action' (Krishnan, 2010: 136-140).

\section{Evolution of the Bottom of the pyramid (BOP) discourse}

One well known and influential literature is the so-called 'BOP literature'. The notion of BOP was introduced by Prahalad in 2005 in his book 'The fortune at the bottom of the pyramid: eradicating poverty through profits' (Prahalad, 2010): We will introduce this as 'BOP1'. . The main argument posited by Prahalad's work is that the poor are un-served consumers who represent an immense unexploited market. In this frame, those at the BOP are positioned as being excluded from mass consumption because of their very limited purchasing power. By targeting the poor, the private sector would have access to new and unsaturated markets and the poor in turn would gain access to consumer goods that are currently inaccessible because they are too expensive. In a nutshell: 'doing more with less and for more people' (Prahalad \& Mashelkar, 2010; Prahalad, 2010, 2012). According to these scholars, those institutions that 
would be best placed to implement such a strategy are MNCs (Kanter, 2008; Rosenbloom \& Althaus, 2007). The underlying philosophy of the BOP approach is that the quest for profit can simultaneously generate economic growth and deliver social value: 'making money by doing good' (Agnihotri, 2013; Bardy, Drew, \& Kennedy, 2012; Chakravarti, 2007; Faulconbridge, 2013; Seelos \& Mair, 2007). By attempting to address problems faced by the poor, BOP innovators can also contribute to creating a new way of innovating (Anderson \& Markides, 2007).

BOP initiatives in China, India and Brazil, for example, appear to follow four different strategies (Prahalad \& Mashelkar, 2010; Prahalad, 2012): (i) Applying disruptive business models to acquired western technology; (ii) Inventing new uses and business models for acquired technology; (iii) Creating new technologies rooted in local contexts; (iv) Creating new business models to exploit endogenous technology.

In a review of the BOP literature, Kolk et al. (2013) analysed 104 articles published in journals or proceedings over a 10-year period (2000-2009) and concluded that the BOP concept had drastically evolved following Prahalad's original call to MNCs. This first formulation of the BOP perspective (following (Arora \& Romijn, 2011) and which I have referred to as 'BOP 1') has been further elaborated to overcome the lack of institutional perspective inherent within Prahalad's original work. In the BOP 1, the actors are depicted as isolated, Randian subjects ${ }^{8}$ without any attempt to describe the institutional, cultural and even historical settings that are at the base of poverty. The following literature identified by Kolk et al., that I will call BOP2, updates the 'poor-as-consumers' perspective by analysing the criticisms levelled at the BOP1 perspective (an example of BOP2 narrative analysis is described in Erreur ! Source du renvoi introuvable.). In the book 'Next Generation Business Strategies for the Base of the Pyramid (London \& Hart, 2011), Hart and London revisited the BOP1 perspective, introducing the concept of 'co-creation with the poor'. This new framing still however emphasises a central role for MNCs in eradicating poverty in which the co-production of economic profit and social value underpinned by a free market economy, innovation and western style democracy is still key (London \& Hart, 2004; London, 2009). The BOP2 perspective emerges in part from observations made by London \& Anupindi (2011), who compared donor-led initiatives with enterprise-led ones, finding that both approaches have common failures which include the lack of local stakeholder involvement and long term sustainability. London and Hart (2004)

\footnotetext{
${ }^{8}$ The crucial role of 'heroic individuals' in the race of progress has been periodically acknowledged from Adam Smith to Joseph Schumpeter. More recently, Ayn Rand (1964) in her book 'The Virtue of Selfishness: A New Concept of Egoism' revisits the notion of the heroic individuals as engines of social change in the perennial quest for personal happiness (rational self-interest). Rand was convinced that the only system consistent with the innate inclination for self-interest typical of human being is laissez-faire capitalism.
} 
discovered that successful initiatives at the BOP imply a strong commitment to establishing alliances and participative ventures with local actors and local institutions. London et al. (2014), for example, found that local institutions and social networks influence purchasing decisions at the BOP in rural India and as a consequence they suggest drawing on those webs of relationships to promote BOP products; Ramani et al. (2012) found that the role of local intermediaries is crucial to the diffusion of BOP innovation in the field of water sanitation in India; Sesan et al. (2013) analysed the diffusion of clean-cook stoves in Nigeria and concluded that its success was mainly due to the collaboration between for-profit ventures and local NGOs; Weidner et al. (2010) by analysing several cases of innovation at the BOP, explored the strategies currently being used across social enterprises engaged in subsistence marketplaces and concluded that the most successful are those with a strong relation with local actors.

Furthermore, some authors have attempted to overcome the limitations of the BOP1 framing by introducing the notion of 'capability building' (Ansari, Munir, \& Gregg, 2012), some have delved into marketing strategy (Mason, Chakrabarti, \& Singh, 2013), some have explored the potential of BOP initiatives to deal with gender issues (Dolan, Johnstone-Louis, \& Scott, 2012), and finally others have applied the BOP framework to microfinance (Chakrabarty \& Erin Bass, 2013; Jose \& Buchanan, 2013; Karamchandani, Kubzansky, \& Lalwani, 2011; Reeves \& Sabharwal, 2013; Sonne, 2012) and to ICT for development (Akter, Ray, D'Ambra, \& D'Ambra, 2013; Dash, Patwardhan, \& Verma, 2011; Foster \& Heeks, 2013b; Gamboa, 2009; Tarafdar, Anekal, \& Singh, 2012; Tarafdar, Singh, \& Anekal, 2013). Finally, a surprising minority of other authors (considering the increasing interest in climate change and environmental issues in the last two decades), have attempted to expand the outcomes of the BOP initiatives to include environmental issues and climate change. Hart et al. (2003), for instance, discuss the inclusion of clean technology and pollution prevention alongside BOP strategies to meet 'unmet needs'. Other authors argue that the struggle for survival of the poor is one of the causes of environmental degradation and the BOP approach could reduce the pressure on the environment by increasing the income of the poor (Hahn, 2008; Hart, 2011; Viswanathan, Yassine, \& Clarke, 2011). Hart (2011) introduces the concept of 'green leapfrog' or 'trickle-up' effect. As eco-friendly technologies and practices always represent a disruptive change in developed countries, where standard technologies are well established, they are often hampered by the pre-existing technological regimes. Those constrains are often looser at the BOP. The absence of technological lock-in and the lack of strong legal frameworks to enforce specific socio-technical regimes might potentially provide a way for the development of a huge variety of alternative technological paths. In this view, the BOP environment is a fertile ground 
to test and experiment sustainable technologies, like off-the-grid energy production, organic farming or micro-finance.

\section{Critics of the BOP approach}

From the literature review, the BOP1/2 narratives emerge as dominant frames in the business and management literature. This approach, however, risks neglecting the social causes of poverty. As Arora and Romijn (2011) notice, this inclination 'promoted at the same time as advancing the spread of neoliberalism over the planet, perhaps to compensate for, and foster, the effective withdrawal of state support for welfare provision to the poor. These authors, quoting the work of S. B. Banerjee (2012) on Corporate Social Responsibility and Willmott (2008) on critical management, hypothesise that the BOP and the inclusive innovation discourses, by using a depoliticised rhetoric of inclusion and participation, neglect the existence of unequal global and local power relations that shape the process of technological change and innovation. They write:

[...] the BOP literature is rapidly inching toward a new corpus of apolitical management studies for managing the (adverse) incorporation of the poor into world markets and further neoliberalization of extremely indigent areas of the planet. Such an apolitical understanding of complex social dynamics, by masking extant privilege and its consolidation will only serve to reproduce existing inequalities at the local level and further entrench the dominance of national and global capitalist formations. '(Ibid.: 497)

Despite its hegemonic position within the business community, the BOP narratives have been the subject of increasing criticism (Arora \& Romijn, 2011; Kolk et al., 2013; Landrum, 2007). Right from the first appearance of Prahalad's book, the BOP approach as a way to alleviate poverty has been questioned (Walsh, Kress, \& Beyerchen, 2005). According to those authors, the BOP approach fails to understand the effects of MNCs strategy on socio-economic development in the developing world. One of the sharpest criticisms comes from one of Prahalad's colleagues at the University of Michigan, Aneel Karnani (2011b: 149) who writes:

'This romanticized view of the poor harms the poor in two ways. First, it results in too little emphasis on legal, regulatory and social mechanisms to protect the poor who are vulnerable consumers. Second, it overemphasizes microcredit and underemphasizes fostering modern enterprises that would provide employment opportunities for the poor. More importantly, it grossly underemphasizes the critical role and responsibility of the state in poverty reduction'

Many feminist NGOs for example strongly criticised the case of Unilever's advertisement of skin whitening products that allegedly promoted racist messages among disadvantaged 
women in rural India (Karnani, 2007a, 2007b, 2007c, 2010, 2011a). Moreover, the environmental perspective, Pitta et al. (2008) argue, is almost untouched. Selling shampoo in smaller packaging, as Prahalad suggests and Procter \& Gamble is already doing in India, will actually increase waste with minimum impact on the poor's welfare. Jaiswal (2007) and Schwittay (2011) showed that marketing products does not necessarily enhance the poor's wellbeing, meant as a social process with material, relational, and subjective dimensions (S. C. White, 2010). On the contrary it increases the probability of being abused by MNCs interests whilst not addressing the social and political causes of exclusion. Moreover, recently MNCs do not seem to have changed drastically their business strategy towards the BOP: on the contrary in many cases they have been discouraged to approach the BOP for the institutional uncertainty that characterises this context (Harjula, 2005).

\section{Appropriate technology and grassroots innovations}

The consumption-based perspectives described above have been opposed by social movements (Abrol, 2005), grassroots movements (Smith et al., 2014) and many NonGovernmental Organisations (NGO) (Hopwood, Mellor, \& O'Brien, 2005; Smith, 2005). Social and grassroots movements have been more concerned with empowering local communities and enhancing the indigenous potential to innovate (Seyfang \& Haxeltine, 2012). Moreover grassroots perspectives acknowledge technology and innovation are neither socially nor politically neutral, nor sufficient to overcome the problems of poverty and social exclusion (Burnett, Senker, \& Walker, 2010) and global justice within a capitalist setting (Papaioannou, 2011).

A first attempt to develop a bottom-up approach to innovation and technology was the seminal work of Schumacher in the 1970s that ignited the debate on the notion of 'intermediate or appropriate technology'. Schumacher's approach privileges people over markets when he explicitly states: "Instead of mass production, we need production of the masses" (Schumacher, 1973). According to Schumacher, the quest of developing countries to catch up with industrialized countries by making a technological leap would increase inequality and poverty. The underling idea behind this approach is that technology is just a partial and temporary solution to problems that are fundamentally social (Smith, 2005); as a result, the approach focuses on innovation capability of common people and communities to generate more socially just and situated technological solutions (Kaplinsky, 1990). The appropriate technology movement originated in the 1960s as part of the debate about international aid and development programs and remained a distinct, identifiable movement until the early 1980s. In the intentions of its activists, the movement aimed at reformulating technology as a tool for 
development (Ibid.). According to A. Smith (2014), although heterogeneous across different countries, the appropriate technology movements have a set of common features:

Iow in capital cost; use local materials; create jobs, employing local skills and labour; small enough in scale to be affordable for small groups; understood, controlled and maintained by local people wherever possible, without requiring a high level of Western-style education; suppose some forms of collective use and collaboration; avoid patents and property rights' (Ibid.: 118)

By the end of the 1970s, organizations active in appropriate technology were present in about 90 different countries, some of which enjoyed financial support from the state (Smith et al., 2014; Smith, 2005). Despite its diffusion, the movement quickly lost its momentum in the early 1980s. The origin of the movement might be found in the frustration many development practitioners had with the top-down industrial blueprint imposed in the post WWII period (Rist, 2011), see previous chapter. By the end of the 1970s many of the principles of the movement had been accepted by the mainstream scholars of development (Smith et al., 2014). However, the neoliberal turn embodied in the agenda of Structural Adjustments promoted by the World Bank shifted innovation policy towards the model of technological catch up, seeking to replicate the successful experience of the East Asian countries (Kaplinsky, 2011). Furthermore, according to Smith et al. (2014), the movement failed to fulfil its promises of delivering community empowerment and promoting local ingenuity. The vast majority of the appropriate technology projects, indeed, were carried out by well-intentioned engineers on the basis of their assumptions about what poor people needed. Moreover, the movement failed to acknowledge that the solutions to the problems they intended to address mainly involved engaging with local power relations (Ibid.). Gender, class and ethnicity in many cases hampered participation. Technology was not able to reverse those relations without radically questioning the political structures within which appropriate technology initiatives operated (Ibid.).

The principles of the appropriate technology movement nowadays have been revisited by grassroots innovation movements (see also an example of Grassroots Innovation narrative analysis in Erreur ! Source du renvoi introuvable.). A. Smith et al. (2014) identify at least three major grassroots groups in developing countries: the People's Science Movement and the Honey Bee Network in India (see Chapter 10 where I will investigate the first of these in more detail) and the technologies for social inclusion movement in Latin America. This phenomenon is present in low-income countries but it has also diffused in industrialized countries as several scholars (Seyfang \& Smith, 2007), especially in the UK, have proved: Hargreaves et al. (2013) and Ornetzeder \& Rohracher (2013) documented the grassroots 
innovation in the field of 'community energy projects' and the strategies deployed to diffuse them; Kirwan et al. (2013) analysed social grassroots innovations in the food sector; Monaghan (2009) documented the creation of grassroots innovation niches in the sector of body disposal; White \& Stirling (2013) focused on the evolution of 'communal growing' initiatives, their dynamics and diversity. Some of these scholars have also explored the potential of grassroots initiatives to start a transition towards an environmental and socially sustainable new society (Feola \& Nunes, 2014; Seyfang \& Haxeltine, 2012; Seyfang \& Longhurst, 2013a; R. White \& Stirling, 2013). Other aspects of grassroots innovation have been analysed by those scholars interested in user-led innovations. Low-cost innovation niches, for instance, are highly diffused among lead users in developed countries in different fields, serving to decrease the innovation cost with respect to formal R\&D activities (Von Hippel, 2005). The rising phenomenon of the DIY culture of the makers' movement is another example of grassroots innovation (Honey \& Kanter, 2012; The-economist, 2011). Other examples of grassroots, user-led innovation can be found in the cases of Desobedencia tecnologica (technological disobedience) documented in Cuba by the designer Ernesto Oroza 9 .

Within the scant academic literature focused on grassroots innovation in the Global South, the work of Anil Gupta is particularly relevant. According to Gupta (2012), innovation that stems from the poor to the poor is not a novel phenomenon, but he frames it in a rather particular way in terms of its social and cultural constitution. Rather that pursuing exclusively the innovation of novel products appropriate for the BOP context underscored by a profit motive for MNC's (with social goals such as alleviation of poverty envisaged as being co-produced), indigenous grassroots innovators innovate to address problems that are essentially and primarily social. These bottom-up perspectives refute the essentialist idea that poverty is caused by a direct lack of income and consumption potential. Thus, it is not a surprise that such innovation is empathetic (Gupta, 2010) or pursues objectives other than more consumption, profitability or ever increasing incomes (Ansari et al., 2012). According to Gupta (2009), who founded the Honey Bee Network devoted to scouting grassroots innovators in rural India, scientists do not seem to be interested in frugal innovation. Perhaps even more importantly, formal institutions have not been interested in embedding frugal innovation potential in mainstream innovation policy (Fressoli et al., 2014). Instead of adapting national policy to develop specialised fields of technology for the benefit of big industry, frugal innovation policy would focus on the specific needs of local communities and empower people to have control of technology (Gupta, 2010). Smith et al. (2012) documented the activity of

\footnotetext{
${ }^{9}$ Available at: http://www.ernestooroza.com/tag/desobediencia-tecnologica/
} 
several formal and informal networks of grassroots innovators in developing countries. Among these cases, Smith et al. (2014) have documented the institutional links and the public support raised by networks for social technology active in Argentina, Uruguay and Brazil. The networks are supported by public institutions as well as by private organizations. However, despite the increasing interest and support to those initiatives showed by the political elites of those continents, grassroots innovations are still considered a form of social intervention rather than an alternative to the mainstream of the industrial innovation policy. According to some authors, despite their limited impact, grassroots innovations are an important alternative source of knowledge that should be taken very seriously. Smith $(2005,2007)$, suggests that small scale grassroots initiatives generate relevant knowledge to formulate alternatives for sustainable innovation policy. Demeritt et al. (2011) argues that, despite its limited impact, grassroots innovation opens up the space for debating alternative pathways to sustainable futures. Finally Smith el al. (2014) argues that grassroots innovations offer three challenges for the process of socio-technical change:

- Locally-specific, yet widely-applicable: grassroots ingenuity stimulates the search for context-based innovation that can be potentially applied in a number of different contexts that share common features like material and human resource scarcity.

- Appropriate to, yet transforming situations: grassroots innovation encourages the emergence of socio-technical practices under different value systems that can be very different form the profit-driven innovation of the business-as-usual

- Project-based solutions, yet seeking structural change: grassroots movements stimulate the debate about social reform and encourage the structural critique to the present economic and political structures.

\section{An emerging overarching discourse: Inclusive growth and inclusive innovation}

More recently both top-down, consumption based and bottom-up, grassroots perspectives have been combined within concepts that include 'inclusive growth' (George et al., 2012) (see Figure 2), 'inclusive development' (I. Sachs, 2004; World Bank, 2008), 'inclusive innovation' (Altenburg, 2009; Heeks, Foster, \& Nugroho, 2014; Nijhof, Fisscher, \& Looise, 2002), 'Inclusive innovation systems' (Foster \& Heeks, 2013a) and 'Inclusive Business Models' (UNDP, 2008). The concept of 'inclusive growth' has also been enthusiastically used in the context of more advanced economies such as the EU (Guth, 2005). Although vague and heterogeneous, the concept of inclusiveness in these three formulations (i.e., development, growth and innovation) advocates for a more equal and fair distribution of the economic benefits of innovation, development and economic growth, evoking concepts of social justice 
and equity (Cozzens \& Sutz, 2012; Papaioannou, 2011). One reason for this lack of specificity may lie in the fact that the concept of inclusiveness is a buzzword that encloses a huge number of notions, meanings and frameworks.

The notion of inclusivity was first introduced in the academic context by I. Sachs (2004) who forged the concept of 'inclusive development'. Drawing on a historical analysis of successive conceptualizations of development he proposed the coordination of policy efforts to find a balance between economic efficiency, decent work and environmental protection. He wrote:

'Given the unruliness of the globalization process, national-level policies must be relied upon to bring the excluded into the economic mainstream, notably by helping informal-sector workers make the transition to formal entrepreneurship'. (I. Sachs, 2004: 161)

More recently, the concept has been transformed through the idea of 'inclusive growth' (Kanbur \& Rauniyar, 2010; Rauniyar \& Kanbur, 2010; Sengupta, 2010). Kanbur and Rauniyar (2010: 445) wrote:

'the main argument is that a growth process becomes inclusive when every individual has access to the different elements of the well-being, without being prevented from enjoying these rights because of any legal and social barrier'.

The underling perspective of inclusivity, although elaborated by several authors with distinct perspectives, is very straightforward: the process of development, while it has created richness for a few people, has excluded a vast portion of humanity. The question as to what type of innovation can produce inclusive development (and how) remains one on which the academic community is divided. As I showed earlier, at least in the business and economic community the BOP perspective appears to be highly influential or even dominant when compared to the grassroots perspective. The main argument of the BOP $1 / 2$ supporters is that organizations (i.e., MNCs) can and must engage in social innovation activities to empower disadvantaged groups and foster social and economic growth. Similar to the BOP1/2 approach, inclusive innovation promotes the development of innovative capability to produce low-cost, reasonable quality products or business models in developing countries which are then exported to other low-income countries. According to George et al (2012), inclusive innovation is the "development and implementation of new ideas which aspire to create opportunities that enhance social and economic well-being for disenfranchised members of society". 
With regard to grassroots innovation the solutions proposed are very diverse and heterogeneous. A first group of scholars focuses on the notion of equality and technical change (Cozzens \& Kaplinsky, 2009; Cozzens, 2007; Papaioannou, 2011). Is innovation itself creating inequality or rather is it the distribution of wealth originating from such innovation that is inefficient? There is empirical evidence that suggests inequality both hinders development and presents an obstacle to innovation (Cozzens \& Kaplinsky, 2009; Cozzens, 2007, 2008). In short, if economic growth is not accompanied by other measures like the improvement of educational, health and welfare systems that diminish inequality, then further development and growth could be jeopardised. Other scholars have proposed a rediscovery and upgrading of traditional ways of production as a way to build an inclusive economy, which reinforce or rebuild local linkages between people and the environment (Gupta, 2010b; Gupta et al., 2003; J. Martinez-Alier, 2008; Thomson, 2011). A minority, but increasing group is exploring nonmainstream economics thinking to overcome to need to 'include the poor' within the capitalist system. The 'de-growth' community, for example, criticises what they call the 'religion of growth' and advocates for a new kind of inclusive development outside the paradigm of economic growth (Fournier, 2008; Jackson, 2009; Kallis, 2011; Joan Martinez-Alier, 2009; van Griethuysen, 2010). Finally local community experiments propose the use of 'alternative currencies', auto-production and local markets to strength local economies (Seyfang \& Longhurst, 2013a, 2013b). These kinds of experiments seem to be increasing in number, but are not yet on the radar of the majority of the academic community.

\section{Discussion}

We argue that the debate about technical change, poverty and development is alive and kicking. The business and management communities have now joined their colleagues in development studies to contribute to this debate, re-shaping the way academia understands and frames crucial concepts such as development, poverty and well-being, through narratives of e.g. innovation and inclusive business models. This cross-pollination has created diverse and heterogeneous frames (Erreur! Source du renvoi introuvable. is a non-exhaustive summary of the narratives identified). It is virtually impossible to classify the literature analysed into a set of clearly defined and fixed categories. Any taxonomy will degrade the complexity of each approach and would not take into account the fact that ideas, meanings and principles overlap and are dynamic in practically all the works considered.

Table 1 Innovation and development narratives 


\begin{tabular}{|c|c|c|c|c|}
\hline BOP 1 & MNCs & $\begin{array}{l}\text { MNCs have to transform the } \\
\text { poor into consumers by } \\
\text { providing affordable products }\end{array}$ & $\begin{array}{l}\text { Opening underserved markets. } \\
\text { Fighting poverty with a profit based } \\
\text { approach }\end{array}$ & (Prahalad, 2010) \\
\hline BOP 2 & $\begin{array}{l}\text { Synergies } \\
\text { between } \\
\text { MNCs, small } \\
\text { firms, NGOs, } \\
\text { communities }\end{array}$ & $\begin{array}{l}\text { Adapts BOP1 in that MNCs can } \\
\text { serve better the BOP by } \\
\text { creating alliances with local } \\
\text { agents }\end{array}$ & $\begin{array}{l}\text { Opening underserved markets by } \\
\text { fostering global-local cooperation }\end{array}$ & $\begin{array}{l}\text { (Hart \& } \\
\text { Christensen, 2002; } \\
\text { London \& Hart, } \\
\text { 2004; Prahalad \& } \\
\text { Mashelkar, 2010) }\end{array}$ \\
\hline $\begin{array}{l}\text { Bricolage, } \\
\text { Frugality, } \\
\text { Jugaad }\end{array}$ & $\begin{array}{l}\text { Any firm or } \\
\text { individual }\end{array}$ & $\begin{array}{l}\text { "Doing more with less" for } \\
\text { necessity as an individual, for } \\
\text { growth as a firm }\end{array}$ & $\begin{array}{l}\text { Reduce resource use and/or create } \\
\text { competitive advantages }\end{array}$ & $\begin{array}{l}\text { (Baker \& Nelson, } \\
\text { 2005) }\end{array}$ \\
\hline $\begin{array}{l}\text { Grassroots } \\
\text { innovation, } \\
\text { Appropriate } \\
\text { technology }\end{array}$ & $\begin{array}{l}\text { Common } \\
\text { people and } \\
\text { communities }\end{array}$ & $\begin{array}{l}\text { Ingenuity of the poor is huge } \\
\text { and must be promoted by } \\
\text { public institutions to create } \\
\text { affordable and inclusive } \\
\text { solutions }\end{array}$ & $\begin{array}{l}\text { Empowerment of local } \\
\text { communities. Meeting basic needs } \\
\text { endogenously. }\end{array}$ & $\begin{array}{lr}\text { (Gupta, } & 2012 ; \\
\text { Seyfang } & \& \\
\text { Haxeltine, } & 2012 ; \\
\text { Smith et al., 2014) }\end{array}$ \\
\hline $\begin{array}{l}\text { Inclusive } \\
\text { growth }\end{array}$ & Any & $\begin{array}{l}\text { Economic development/growth } \\
\text { alone is not sufficient to } \\
\text { distribute equally its benefits }\end{array}$ & $\begin{array}{l}\text { To extend the benefits of economic } \\
\text { development/growth to those who } \\
\text { have been excluded Equality, } \\
\text { wellbeing improvement, } \\
\text { empowerment. }\end{array}$ & $\begin{array}{l}\text { (George et al., } \\
2012 ; \text { I. Sachs, } \\
2004)\end{array}$ \\
\hline
\end{tabular}

\section{Innovation as a battle field of competing narratives}

The literature analysed, nevertheless, presents at least three major trends: Business-as-usual, reform and transformation. The first trend tends to transfer laissez faire, neo-liberal principles into the development field and, as a consequence, considers development-oriented technological change/innovation as something compatible with and achievable within free market dynamics. This trend is clearly visible in the early BOP literature. The poor are conceived as 'recipients of innovation' and consumers. In the more recent BOP literature this trend has being modified by adding complexity to the way scholars look at the field. They realised that turning the poor into consumers of products designed elsewhere did not even scratch the surface of the complex phenomenon of poverty and underdevelopment. As a consequence they developed a number of refined formulations of this perspective to overcome the narrow view of the pure market-driven innovations. The BOP2 narrative considers the poor as co-producers, intermediaries and in some cases even entrepreneurs. The business-asusual perspective is replaced by a scenario open to alliances and collaborations between stakeholders with very different backgrounds and motivations (i.e., NGOs, local communities, small and big firms).

The second trend (i.e., 'reform') that emerges from the review remains only marginally influential in the academic arena. This trend is advocated by those who focus on the countervailing movements at the margin of the dominant discourse of neo-liberal expansion. This trend looks at the poor, but more generally at 'common people', as potential selforganised producers and entrepreneurs. This is, of course, a hugely variegated group that 
include a few scholars and also activists, practitioners and even indigenous groups. The underling discourse that shines through this heterogeneous and scant literature is a call to reform the current, locked - in development paradigm based on the mono-culture of market mechanisms. They also stress the idea that 'technological innovation is a contextual process whose relevance should be assessed depending on the socio-economic condition it is embedded in' (Srinivas \& Sutz, 2008: 129).

Finally, a very small minority (i.e., the 'transformation' group) openly question the model of development that has been promoted in the post-WWII era (Fournier, 2008; Kallis, 2011; van Griethuysen, 2010). This community questions the basis of the notion of development and progress: i.e. the fact that history is a linear evolution of never-ending progress where technological and economic growth is always inevitable and necessary.

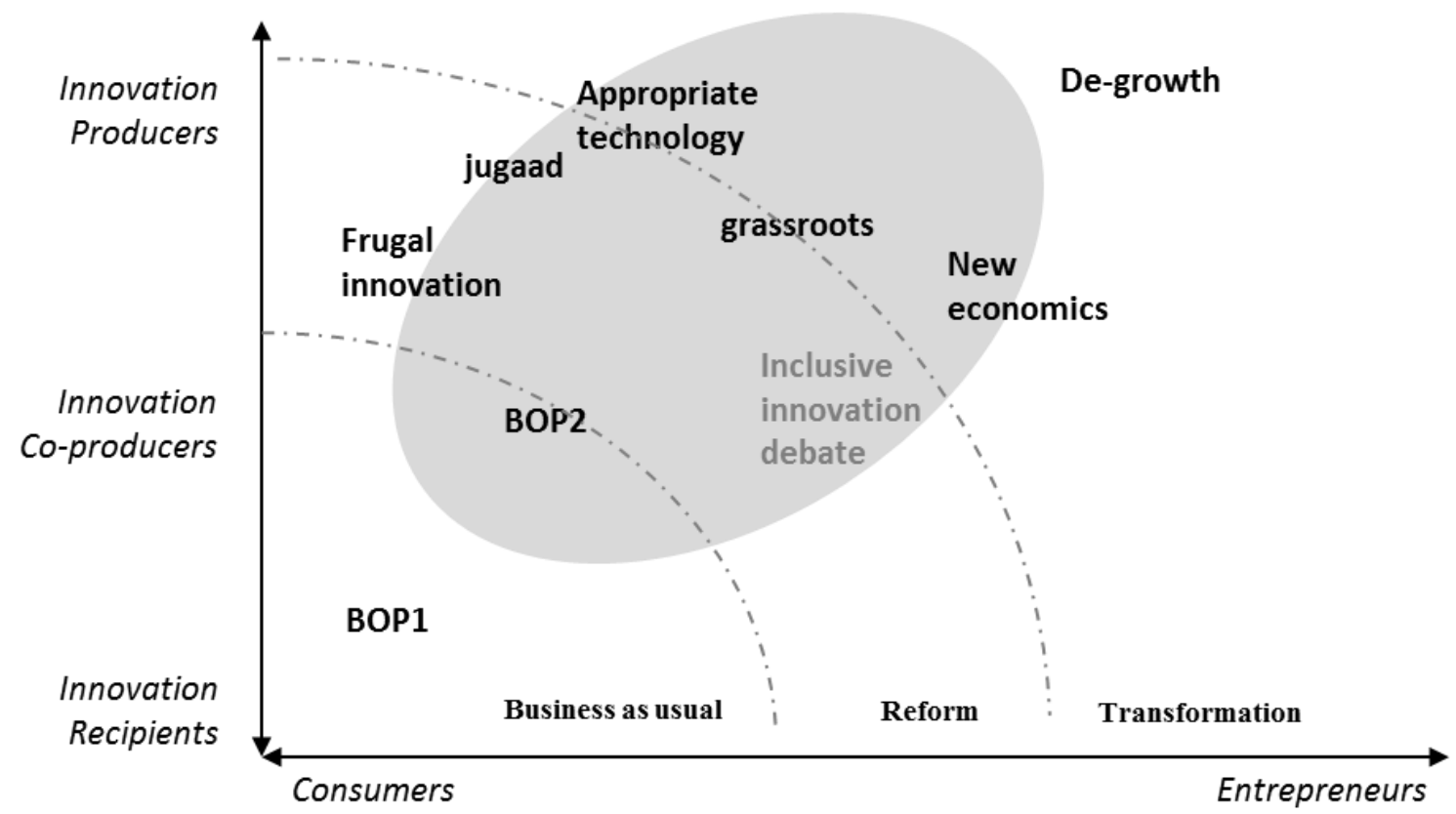

Figure 2 Framing innovation for development

\section{New Research Directions: Opening up the debate about innovation and development}

As we attempted to show above, the notion of innovation is at the centre of a discursive battle between diverse narrative, world view or ideologies of development. It is worthwhile to notice that, from the post-war period, the discourses of development, science and technology have been strongly intertwined. This connection has influenced the discourse of development from the end of WWII, usually assuming the form of 'Technical Assistance' or 'Technical Cooperation' conceived as furnishing experts' advice to those countries that require 
assistance. As documented by Wilson (2007), these discourses have been reframed to conceive a more articulated role of technological change and innovation in the development process. The focus on IS, learning processes and knowledge management that characterises the new generation of development interventions is a sign of this evolution (Ibid). On the other hand, according to Krause (2013), there is an increasing use of the word 'innovation' in the development literature and in the discourse of the practitioners in the field. At the same time, she notices, the word assumes a huge variety of meanings, depending on the context in which is used. This increasing popularity of the word innovation leads her to wonder if we are in front of another form of Big Push rhetoric (i.e. the mantra, popular in the 1950s, of modernization that preached the industrialization of the 'third world' (Easterly \& Sachs, 2006)) or a radical shift in the development discourse. The umbrella term 'innovation' is being increasingly used in the discourse of several development institutions including, the UN agencies like UNICEF and the UNHRC. The use of the word innovation might be interpreted as a tendency to look for a 'technical fix' in the fight against poverty, scarcity, economic stagnation and all 'the symptoms of underdevelopment'. This ideology is usually framed in terms of 'Inclusive Growth', a form of human capitalism, which has to be pursued through 'inclusive forms of innovation' (George et al., 2012). This reshaped ideology of growth hides a process of depoliticization of the discourse of development. As Arora and Romijn (2011) notice, this inclination 'promoted at the same time as advancing the spread of neoliberalism over the planet, perhaps to compensate for, and foster, the effective withdrawal of state support for welfare provision to the poor'. These authors, quoting the work of S. B. Banerjee (2012) on Corporate Social Responsibility (CSR) and Willmott (2008) on critical management, hypothesise that the BOP discourse, by using a depoliticised rhetoric of inclusion and participation, neglect the existence of unequal global and local power relations that shape the process of technological change and innovation. They write:

[...] the BOP literature is rapidly inching toward a new corpus of apolitical management studies for managing the (adverse) incorporation of the poor into world markets and further neoliberalization of extremely indigent areas of the planet. Such an apolitical understanding of complex social dynamics, by masking extant privilege and its consolidation will only serve to reproduce existing inequalities at the local level and further entrench the dominance of national and global capitalist formations.'(Ibid.: 497)

What emerges from the BOP narratives, for example, is not only just a neutral approach to development but a specific ideological view of the world. The emphasis on concepts as profits, customers/clients relations, markets, business ventures etc. tends to hide the existence of countervailing types of discourses of development that traditionally focus on concepts like social justice, equality, and democracy. Based on those reflections, Leach \& Scoones (2006) argue that the discourse about technical change, innovation and development is still polarised 
in what they called the 'three races'. The first race, which is also the dominant one according to the authors, is the 'race to the top of global economy' where science and technology are seen as the fundamental ingredient to achieve economic growth in a highly competitive world. The narrative of development that underlies this race is the view of development as modernization, assuming that developing countries will move through a sequence of stages towards industrial modernity. In this view, it is generally assumed that poverty would be reduced by a trickle-down effect of the benefits of economic growth. A second race is the 'race to the universal fix', which assumes that major breakthroughs in science and technology will have a decisive impact on poverty. New revolutionary advances in agriculture, new mobile phone technologies, and new vaccines among other technological artefacts are all examples of 'universal fixes'. In this view, development is a global overarching process that is morally committed to provide scalable and transferable universal solutions on a large scale. As W. Sachs (1990:14) argues, the popularity of this idea derives from 'the tragic fallacy that modern technologies possess the innocence of tools'. Throughout North and South, the consensus is that 'more technology' is always better because technology is seen as a powerful but neutral means. There is then a third 'slower race' that Leach et al. (2008) define as follows:

\begin{abstract}
[the slower race] emphasises pathways to poverty reduction which, while recognising the importance of science and technology, are specific to local contexts; recognise that technological fixes are not enough and that social, cultural and institutional dimensions are key; create hybrids between local and external knowledge for appropriate solutions, and go the extra mile to make already-existing technologies more readily available to those who are poor and marginalised. In this view, science and technology are a part of a participatory process of development where citizens themselves take centre stage. Rather than passive beneficiaries of trickle-down development or technology transfer, citizens are knowledgeable, active and centrally involved in both upstream technology choice and design, and downstream deliberations around technology delivery and regulation-perhaps challenging external perspectives. This, so the policy argument goes, makes for technologies more appropriate to the challenges of poverty reduction and social justice.' (Ibid.: 730)
\end{abstract}

The slower race originates from the acknowledgement that the dynamics of technological change, far from being a singular path to progress, imply several complex, power-influenced processes, often contradictory with each other, that move in a huge variety of different directions. These dynamics might imply the marginalisation and exclusion of some social sectors and, at the same time, benefit other people by providing economic growth and greater well-being. Technology is far from being a collection of neutral tools, rather becomes a system of intertwined systems that requires profound social transformation to function properly. Once 'technical development' is embraced, 'no society can stay the same' (W. Sachs, 1990: 15); there can be no technical modernization without remodelling the whole of society arrangement. In this view, the questions about power, political economy, the impact of planned 
development interventions and who gains and who loses from these are crucial to understanding the directions of technical change.

\section{Conclusions}

The word innovation - and all its variants such as frugal, grassroots, BOP, inclusive, blowback, reverse, gandhian, jugaad or resource constrain innovation - might be suitably welcome in the family of what Cornwall (2007) calls the development's buzzwords. Innovation owns all the characteristics of a typical buzzword. It conveys a reassuring positive meaning loaded with expectations about a bright future i.e., the new is always better and the future will be better than the present. It is an apolitical and trans-ideological term that attracts the attentions of a wide range of actors even from rival ideological backgrounds. As a buzzword, innovation bridges separated discursive worlds such as the discourse of development and the discourse of Science \& Technology. The ascendency of the buzzword innovation in the development's discourse is relatively recent and it interestingly overlaps with the rise and affirmation of neoliberal discourse as a dominant narrative among the development practitioners, international donors, public institutions and scholars. In the last three decades, the word 'innovation' has conquered our imaginary. It embodies a renewed optimism, a reinvigorated faith in the progress, a brilliant future plenty of novelties. Similarly to the idea of development, innovation renews the promise of a never ending progress in which tomorrow will be better than today.

This article shows that the recent evolution of the discourse of development is increasingly intertwined with elements that originated in other discursive worlds. The focus on technological change and in particular on its neoliberal formulation framed in terms of innovation and competitiveness has become central in the development practice. The original mission of 'development cooperation' turned into the 'development of competition'. The examples illustrated by the new trend of business studies focused on Frugal, Inclusive or Jugaad innovation show that in the so-called developing word this task in the practice is conducted through a slow transformation of the pre-existing social practices. This change is supported by powerful narratives that legitimise the new practices and present them as inevitable. If they want to survive, poor must be more productive, more competitive, more organised, more educated, more innovative; they must use more energy, they must consume more market products and services. Nevertheless, those narratives are often contested, sometime rejected (Abrol, 2003, 2013). The same happens to those buzzwords that constitute the backbones of those narratives. Words like innovation and technology are twisted and forced to serve 
different meanings that emerges only when one focuses on the localised practices in the field. At the same time, the silent opposition to this project remembers us that there are indeed possible and viable alternatives. As some has proposed (Stirling, 2008), we argue in favour of new research directions that aim at preserving and protecting the variegated forms of survival, subsistence and autonomy typical of non-western societies because they represent a unique pool of diversity. In a world of 9 billion people under the threat of climate change and ecological collapse, in our opinion, such a diversity of narratives might prove vital.

\section{References}

Abrol, D. (2003). People Technology Inititatives: Embedding technology in community-based production systems. In A. J. Hall, B. Yoganand, R. V Sulaiman, \& N. G. Clark (Eds.), Post-harvest innovations in innovation: reflections on partnership and learning (Vol. 4). Patancheru, India \& Aylesford, UK: DFID Crop Post-Harvest Programme South Asia and Natural Resources International Limited.

Abrol, D. (2005). Embedding technology in community-based production systems through People's Technology Initiatives: Lessons from the Indian experience. International Journal of Technology Management and Sustainable Development, 4(1), 3-20.

Abrol, D. (2013). Pro-poor Innovation-making, knowledge production and technology implementation for rural areas : Lessons from the Indian Experience. In S. Ramani (Ed.), Innovation in India: Melding Economic Growth with Inclusive Development. Delhi: Cambridge University Press.

Agarwal, N., \& Brem, A. (2012). Frugal and Reverse Innovation - Literature Overview and Case Study Insights from a German MNC in India and China. In Proceedings of the 2012 18th International Conference on Engineering, Technology and Innovation.

Agnihotri, A. (2013). Doing good and doing business at the bottom of the pyramid. Business Horizons, 56(5), 591-599.

Ahlstrom, D. (2010). Innovation and Growth: How Business Contributes to Society. The Academy of Management Perspectives, 24(3), 11-24. Retrieved from http://amp.aom.org/content/24/3/11.full

Akter, S., Ray, P., D'Ambra, J., \& D'Ambra, J. (2013). Continuance of mHealth services at the bottom of the pyramid: the roles of service quality and trust. Electronic Markets, 23(1), 29-47.

Altenburg, T. (2009). Building inclusive innovation system in developing countries: challange for IS research. In B.-A. Lundvall (Ed.), Handbook of Innovation System and Developing Countries (pp. 33-56). Cheltenham, Uk: Edward Elgar.

Anderson, J., \& Markides, C. (2007). Strategic Innovation at the Base of the Pyramid. MIT Sloan Management Review, 49(49116), 83-88. 
Ansari, S., Munir, K., \& Gregg, T. (2012). Impact at the "Bottom of the Pyramid": The Role of Social Capital in Capability Development and Community Empowerment. Journal of Management Studies, 49(4), 813-842.

Arocena, R., \& Senker, P. (2003). Technology, inequality, and underdevelopment: The case of Latin America. Science Technology \& Human Values, 28(1), 15-33.

Arocena, R., \& Sutz, J. (2000). Looking at national systems of innovation from the South. Industry \& Innovation, 7(1), 55-75.

Arocena, R., \& Sutz, J. (2003). Inequality and innovation as seen from the South. Technology in Society, 25(2), 171-182.

Arora, S., \& Romijn, H. (2011). The empty rhetoric of poverty reduction at the base of the pyramid. Organization, 19(4), 481-505.

Baker, T., Miner, A. S., \& Eesley, D. T. (2003). Improvising firms : bricolage , account giving and improvisational competencies in the founding process. Research Policy, 32(2), 255276.

Baker, T., \& Nelson, R. E. (2005). Creating Something from Nothing: Resource Construction through Entrepreneurial Bricolage. Administrative Science Quarterly, 50(3), 329-366.

Banerjee, S. B. (2012). Corporate Social Responsibility: The Good, the Bad and the Ugly. Critical Sociology, 34(1), 51-79.

Bardy, R., Drew, S., \& Kennedy, T. F. (2012). Foreign Investment and Ethics: How to Contribute to Social Responsibility by Doing Business in Less-Developed Countries. Journal of Business Ethics, 106(3), 267-282.

Bhatti, Y. (2013). Jugaad Innovation: Think Frugal, Be Flexible, Generate Breakthrough Growth. South Asian Journal of Global Business Research, 2(2), 279-282.

Birtchnell, T. (2011). Jugaad as systemic risk and disruptive innovation in India. Contemporary South Asia, 19(4), 357-372.

Blondel, V. D., Guillaume, J.-L., Lambiotte, R., \& Lefebvre, E. (2008). Fast unfolding of communities in large networks. Journal of Statistical Mechanics: Theory and Experiment, 2008(10), P10008.

Bound, K., \& Thornton, I. (2012). Our frugal future: Lesson from India's Innovation System. London. Retrieved from http://www.nesta.org.uk/library/documents/OurFrugFuture.pdf

Brown, J. S. (2005). Innovation Blowback: Disruptive management practices from Asia. McKinsey Quarterly, 1, 35-45.

Burnett, J., Senker, P., \& Walker, K. (2010). The Myths of Technology: Innovation and Inequality. Information Communication Society, 13(7), 1063-1065.

Cassiolato, J. E., Lastres, H. M. M., \& Maciel, M. L. (2003). Systems of innovation and development: evidence from Brazil. Cheltenham, UK; Northampton, MA: Edward Elgar Publishing. 
Chakrabarty, S., \& Erin Bass, A. (2013). Comparing Virtue, Consequentialist, and Deontological Ethics-Based Corporate Social Responsibility: Mitigating Microfinance Risk in Institutional Voids. Journal of Business Ethics, 1-26. doi:10.1007/s10551-0131963-0

Chakravarti, D. (2007). The fortune at the bottom of the pyramid: Eradicating poverty through profits. Journal of Public Policy \& Marketing, 26(1), 152-156.

Cornwall, A. (2007). Buzzwords and fuzzwords: deconstructing development discourse. Development in Practice, 17(4-5), 471-484.

Cozzens, S. (2007). Distributive Justice in Science and Technology Policy. Science and Public Policy, 34(2), 85-94.

Cozzens, S. (2008). Innovation and Inequality. In R. E. Smits, S. Kuhlmann, \& P. Shapira (Eds.), The Theory and Practice of innovation Policy. An International Research Handbook (pp. 134-145). Cheltenham (UK) and Northampton, MA (USA): Edward Elgar Publishing.

Cozzens, S., \& Kaplinsky, R. (2009). Innovation, poverty and inequality: cause, coincidence, or co-evolution? In B.-A. Lundvall (Ed.), Handbook of Innovation System and Developing Countries (pp. 57-82). Cheltenham, Uk: Edward Elgar.

Cozzens, S., \& Sutz, J. (2012). Innovation in Informal Settings: A Research Agenda. Ottawa: , Discussion paper for the GRIID Network International Development Research Centre. Retrieved from http://www.idrc.ca/EN/Lists/Publications/Attachments/1130/IID Framework July 29.pdf

Dagnino, R. (2009). Tecnologia Social: ferramenta para construir outra socieade. (R. Dagnino, Ed.). Campinas: Instituto de Geociencias de UNICAMP.

Dash, M. K., Patwardhan, M., \& Verma, S. K. (2011). Malls for rural entrepreneur in India: An ICT innovation approaches in emergingng Hariyali Kisaan Bazaar. European Journal of Scientific Research, 56(4), 453-461.

Demeritt, D., Dobson, A., Li, T. M., Leach, M., Scoones, I., \& Stirling, A. (2011). Pathways to sustainability: perspectives and provocations. Environment and Planning A, 43(5), 12261237.

Di Domenico, M., Haugh, H., \& Tracey, P. (2010). Social Bricolage: theorizing social value creation in social enterprises. Entrepreneurship: Theory and Practice, 34(4), 681-703.

Dolan, C., Johnstone-Louis, M., \& Scott, L. (2012). Shampoo, saris and SIM cards: seeking entrepreneurial futures at the bottom of the pyramid. Gender \& Development, 20(1), 3347.

Easterly, W., \& Sachs, J. (2006). The Big Push Déjà Vu: A Review of Jeffrey Sachs's "The End of Poverty: Economic Possibilities for Our Time." Journal of Economic Literature, 44(1), 96-105.

Faulconbridge, J. R. (2013). Situated bottom of the pyramid markets and the multinational corporation. Marketing Theory, 13(3), 393-396. 
Feola, G., \& Nunes, R. (2014). Success and failure of grassroots innovations for addressing climate change: The case of the Transition Movement. Global Environmental Change, 24(1), 232-250.

Foster, C., \& Heeks, R. (2013a). Conceptualising Inclusive Innovation: Modifying Systems of Innovation Frameworks to Understand Diffusion of New Technology to Low-Income Consumers. European Journal of Development Research, 25(3), 333-355.

Foster, C., \& Heeks, R. (2013b). Innovation and scaling of ICT for the bottom-of-the-pyramid. Journal of Information Technology, 28(4), 296-315.

Fournier, V. (2008). Escaping from the economy: the politics of degrowth. International Journal of Sociology and Social Policy, 28(11-12), 528-545.

Fressoli, M., Arond, E., Abrol, D., Smith, A., Ely, A., \& Dias, R. (2014). When grassroots innovation movements encounter mainstream institutions: implications for models of inclusive innovation. Innovation and Development, 4(2), 277-292.

Fu, X., Pietrobelli, C., \& Soete, L. (2011). The Role of Foreign Technology and Indigenous Innovation in the Emerging Economies: Technological Change and Catching-up. World Development, 39(7), 1204-1212.

Gamboa, L. F. (2009). Strategic Uses of Mobile Phones in the BoP: Some Examples in Latin American Countries Pyramid (BoP): Quelques exemples pour les paysd' Amérique latine Pyramid" (BoP): Algunos ejemplos para América Latina. Lecturas de Economía, (71), 209-233.

Garud, R., \& Karnøe, P. (2003). Bricolage versus breakthrough: distributed and embedded agency in technology entrepreneurship. Research Policy, 32(2), 277-300.

George, G., McGahan, A. M., Prabhu, J., \& Macgahan, A. (2012). Innovation for inclusive growth: towards a theoretical framework and a research agenda. Journal of Management Studies, 49(4), 662-683.

Gibbert, M., Hoegl, M., and Valikangas, L. (2006). In Praise of Resource Constraints. MIT Sloan Management Review, 48(3), 15-17.

Govindarajan, V., \& Trimble, C. (2012). Reverse Innovation: Create Far From Home, Win Everywhere. Cambridge, Mass.: Harvard Business Press Books.

Gupta, A. (2009, December). Seduce the scientist. Farming Matters, p. 17.

Gupta, A. (2010a). Empathetic innovations: Connections across boundaries. In R. Mashelkar (Ed.), Timeless Inspirator - Reliving Gandhi (pp. 43-57). Pune: Sakal Papers.

Gupta, A. (2010b). Grass green innovations for inclusive, sustainable development. In A. Lopez-Claros (Ed.), The innovation for development report (pp. 137-146). New York: Palgrave Macmillan.

Gupta, A. (2012). Innovations for the poor by the poor. International Journal of Technological Learning, Innovation and Development, 5(1-2), 28-39. 
Gupta, A., Sinha, R., Koradia, D., Patel, R., Parmar, M., Rohit, P., ... Vivekanandan, P. (2003). Mobilizing grassroots' technological innovations and traditional knowledge, values and institutions: articulating social and ethical capital. Futures, 35(9), 975-987.

Guth, M. (2005). Innovation, social inclusion and coherent regional development: a new diamond for a socially inclusive innovation policy in regions. European Planning Studies, 13(2), 333-349.

Hahn, R. (2008). The Ethical Rational of Business for the Poor - Integrating the Concepts Bottom of the Pyramid, Sustainable Development, and Corporate Citizenship. Journal of Business Ethics, 84(3), 313-324.

Hall, J., Matos, S., Sheehan, L., \& Silvestre, B. (2012). Entrepreneurship and Innovation at the Base of the Pyramid: A Recipe for Inclusive Growth or Social Exclusion? Journal of Management Studies, 49(4), 785-812.

Halme, M., Lindeman, S., \& Linna, P. (2012). Innovation for Inclusive Business: Intrapreneurial Bricolage in Multinational Corporations. Journal of Management Studies, 49(4), 743-784.

Hargreaves, T., Hielscher, S., Seyfang, G., \& Smith, A. (2013). Grassroots innovations in community energy: The role of intermediaries in niche development. Global Environmental Change, 23(5), 868-880.

Harjula, L. (2005). Tensions between venture capitalists' and business-social entrepreneurs' goals: Will bottom-of-the-pyramid strategies offer a solution? Greener Management International, (51), 79-87.

Hart, S. (2011). Taking the Green Leap to the Base of the Pyramid. In T. London \& S. L. Hart (Eds.), Next Generation Business Strategies for the Base of the Pyramid. New Approaches for Building Mutual Value (pp. 79-101). Upper Saddle River, New Jersey: Pearson Education.

Hart, S., \& Christensen, C. (2002). The great leap. Driving innovation from the Base of the Pyramid. MIT Sloan Management Review, 44(1), 51-56.

Hart, S., Milstein, M. B., \& Caggiano, J. (2003). Creating Sustainable Value [and Executive Commentary]. The Academy of Management Executive, 17(2), 56-69.

Heeks, R., Foster, C., \& Nugroho, Y. (2014). New models of inclusive innovation for development. Innovation and Development, 4(2), 175-185.

Hoegl, M., Gibbert, M., \& Mazursky, D. (2008). Financial constraints in innovation projects: When is less more? Research Policy, 37(8), 1382-1391.

Honey, M., \& Kanter, D. E. (2012). Design-Make-Play: Growing the Next Generation of Science Innovators. New York: New York Hall of Science.

Hopwood, B., Mellor, M., \& O'Brien, G. (2005). Sustainable development: mapping different approaches. Sustainable Development, 13(1), 38-52.

Horn, C., \& Brem, A. (2013). Strategic directions on innovation management - a conceptual framework. Management Research Review, 36(10), 939-954. 
Illich, I. (1973). Tools for conviviality. New York: Harper \& Row.

Immelt, J. R., Govindarajan, V., \& Trimble, C. (2009). How GE Is Disrupting Itself. Harvard Business Review, 87(10), 56-66.

Jackson, T. (2009). Prosperity without growth? The transition to a sustainable economy. Sustainable Development (p. 136). London: Sustainable Development Commission.

Jaiswal, A. K. (2007, September 1). Fortune at the Bottom of the Pyramid: An Alternate Perspective.

Jose, S., \& Buchanan, F. R. (2013). Marketing at the bottom of the pyramid: service quality sensitivity of captive microfinance borrowers. Journal of Consumer Marketing, 30(7), 573-582. doi:10.1108/JCM-03-2013-0499

Kallis, G. (2011). In defence of degrowth. Ecological Economics, 70(5), 873-880.

Kanbur, R., \& Rauniyar, G. (2010). Conceptualizing inclusive development: with applications to rural infrastructure and development assistance. Journal of the Asia Pacific Economy, 15(4), 437-454.

Kanter, R. M. (2008). Transforming giants. Harvard Business Review, 86(1), 43-52, 136.

Kaplinsky, R. (1990). The Economies of Small: Appropriate Technology in a Changing World. London: Intermediate Technology Press.

Kaplinsky, R. (2000). Globalisation and Unequalisation: What Can Be Learned from Value Chain Analysis? Journal of Development Studies, 37(2), 117-146.

Kaplinsky, R. (2011). Schumacher meets Schumpeter: Appropriate technology below the radar. Research Policy, 40(2), 193-203.

Karamchandani, A., Kubzansky, M., \& Lalwani, N. (2011). Is the Bottom Of the Pyramid Really for You? Harvard Business Review, 89(3), 107-+.

Karnani, A. (2007a). Doing well by doing good-case study: "Fair \& Lovely" whitening cream. Strategic Management Journal, 28(13), 1351-1357.

Karnani, A. (2007b). Fortune at the Bottom of the Pyramid: A Mirage. Business, 49(4), 48109.

Karnani, A. (2007c). The Mirage of Marketing to the Bottom of the Pyramid: How the Private Sector can help Alleviate Poverty. California Management Review, 49(4), 90-112.

Karnani, A. (2010). Failure of the libertarian approach to reducing poverty. Asian Business \& Management, 9(1), 5-21.

Karnani, A. (2011a). Doing Well by Doing Good: The Grand Illusion. California Management Review, 53(2), 69-86.

Karnani, A. (2011b). The Bottom of the Pyramid Strategy for Reducing Poverty: A Failed Promise. In J. K. Sundaram \& A. Chowdhury (Eds.), Poor Poverty: The Impoverishment Of Analysis. London: Bloomsbury Academic and United Nations. 
Keupp, M. M., \& Gassmann, O. (2013). Resource constraints as triggers of radical innovation: Longitudinal evidence from the manufacturing sector. Research Policy, 42(8), 14571468.

Kim, L. (1980). Stages of development of industrial technology in a developing country: A model. Research Policy, 9(3), 254-277.

Kirwan, J., Ilbery, B., Maye, D., \& Carey, J. (2013). Grassroots social innovations and food localisation: An investigation of the Local Food programme in England. Global Environmental Change, 23(5), 830-837.

Kolk, A., Rivera-Santos, M., \& Rufin, C. (2013). Reviewing a Decade of Research on the "Base/Bottom of the Pyramid" (BOP) Concept. Business \& Society, 20(10).

Krause, U. (2013). Innovation: The new Big Push or the Post-Development alternative? Development, 56(2), 223-226.

Kriplani, M. (2008). GE: Reinventing tech for the emerging world. Business Week. Retrieved from http://www.businessweek.com/magazine/content/08_17/b4081068884259. htm

Krishnan, R. (2010). From Jugaad to Systematic Innovation: The Challenge for India. Bangalore: Utpreraka Foundation.

Landrum, N. E. (2007). Advancing the "Base of the Pyramid" Debate. Strategic Management Review, 1(1), 2012.

Leach, M., \& Scoones, I. (2006). The Slow Race Making technology work for the poor. London: Demos. Retrieved from http://www.demos.co.uk/files/The Slow Race.pdf

Leach, M., Sumner, A., \& Waldman, L. (2008). Discourses, dynamics and disquiet: Multiple knowledges in science, society and development. Journal of International Development, 20(6), 727-738.

Lévi-Strauss, C. (1966). The savage mind. Chicago: University of Chicago Press.

London, \& Hart, S. L. (2004). Reinventing strategies for emerging markets: beyond the transnational model. Journal of International Business Studies, 35(5), 350-370.

London, T. (2009). Making Better Investments at the Base of the Pyramid. Harvard Business Review, 87(5), 106-113.

London, T., \& Anupindi, R. (2011). Using the base-of-the-pyramid perspective to catalyze interdependence-based collaborations. Proceedings of the National Academy of Sciences of the United States of America, (17), 1-6.

London, T., Esper, H., Grogan-Kaylor, A., \& Kistruck, G. M. (2014). Connecting Poverty to Purchase in Informal Markets. Strategic Entrepreneurship Journal, 8(1), 37-55.

London, T., \& Hart, S. (Eds.). (2011). Next Generation Business Strategies for the Base of the Pyramid. New Approaches for Building Mutual Value. Upper Saddle River, New Jersey: Pearson Education. 
Lundvall, B., Vang, J., \& Chaminade, C. (Eds.). (2009). Innovation system research and developing countries. In Handbook of Innovation System and Developing Countries. Cheltenham, Uk: Edward Elgar.

Lundvall, B., Vang, J., Joseph, K., \& Chaminade, C. (2009). Bridging Innovation System Research and Development Studies: challenges and research opportunities. In 7th Globelics conference, Senegal.

Martinez-Alier, J. (2002). The environmentalism of the poor: a study of ecological conflicts and valuation. Cheltenham, Uk: Edward Elgar.

Martinez-Alier, J. (2008). Inequality, cooperation, and environmental sustainability. Ecological Economics, 64(4), 912-913.

Martinez-Alier, J. (2009). Herman Daly Festschrift: Socially Sustainable Economic Degrowth. In C. J. Cleveland (Ed.), Encyclopedia of Earth. Washington, D.C.: Environmental Information Coalition, National Council for Science and the Environment.

Martins Lastres, H., \& Cassiolato, E. (2008). Systems of innovation and development from a South American perspective: a contribution to Globelics.

Mason, K., Chakrabarti, R., \& Singh, R. (2013). What are bottom of the pyramid markets and why do they matter? Marketing Theory, 13(3), 401-404.

Monaghan, A. (2009). Conceptual niche management of grassroots innovation for sustainability: The case of body disposal practices in the UK. Technological Forecasting and Social Change, 76(8), 1026-1043.

Muchie, M., \& Gammeltoft, P. (2003). Putting Africa First: The Making of African Innovation Systems. Aalborg, Denmark: Aalborg University Press.

NHS. (2013). Closing the NHS funding gap : how to get better value health care for patients. Retrieved from http://www.monitor.gov.uk/sites/default/files/publications/ClosingTheGap091013.pdf

Nijhof, A., Fisscher, O., \& Looise, J. K. (2002). Inclusive innovation: a research project on the inclusion of social responsibility. Corporate Social Responsibility and Environmental Management, 9(2), 83-90.

Ornetzeder, M., \& Rohracher, H. (2013). Of solar collectors, wind power, and car sharing: Comparing and understanding successful cases of grassroots innovations. Global Environmental Change, 23(5), 856-867.

Pansera, M. (2013). Frugality, Grassroots and Inclusiveness : New Challenges for Mainstream Innovation Theories. African Journal of Science, Technology, Innovation and Development, 5(6), 469-478.

Pansera, M., \& Owen, R. (2014). Framing Resource-Constrained Innovation at the "Bottom of the Pyramid": Insights from an ethnographic case study in rural Bangladesh. Technological Forecasting and Social Change, forthcomin. doi:10.1016/j.techfore.2014.10.004 
Papaioannou, T. (2011). Technological innovation, global justice and politics of development. Progress in Development Studies, 11(4), 321-338.

Peredo, A. (2012). The BOP Discourse as Capitalist Hegemony. Academy of Management Proceedings, 2012(1), 1-1. doi:10.5465/AMBPP.2012.274

Pitta, D. A., Guesalaga, R., \& Marshall, P. (2008). The quest for the fortune at the bottom of the pyramid: potential and challenges. Journal of Consumer Marketing, 25(7), 393-401.

Prahalad, C. K. (2010). The fortune at the bottom of the pyramid: eradicating poverty through profits (2nd ed., p. 407). Upper Saddle River, New Jersey: Pearson Education.

Prahalad, C. K. (2012). Bottom of the Pyramid as a Source of Breakthrough Innovations. Journal of Product Innovation Management, 29(1), 6-12.

Prahalad, C. K., \& Mashelkar, R. A. (2010). Innovation's Holy Grail. Harvard Business Review, July-Augus.

Prathap, G. (2014). The myth of frugal innovation in India. Current Science, 106(3), 374-377.

Radjou, N., Prabhu, J., Ahuja, S., \& Roberts, K. (2012). Jugaad Innovation: Think Frugal, Be Flexible, Generate Breakthrough Growth. San Francisco: Jossey-Bass.

Ramani, S. V., SadreGhazi, S., \& Duysters, G. (2012). On the diffusion of toilets as bottom of the pyramid innovation: Lessons from sanitation entrepreneurs. Technological Forecasting and Social Change, 79(4), 676-687.

Rand, A. (1964). The Virtue of Selfishness: A New Concept of Egoism. New York: Signet.

Rao, B. C. (2013). How disruptive is frugal? Technology in Society, 35(1), 65-73.

Rauniyar, G., \& Kanbur, R. (2010). Inclusive growth and inclusive development: a review and synthesis of Asian Development Bank literature. Journal of the Asia Pacific Economy, 15(4), 455-469.

Reeves, M., \& Sabharwal, N. (2013). Microfinance and mobile banking for the bottom of the pyramid. Journal of Enterprising Communities: People and Places in the Global Economy, 7(2), 155-166.

Rist, G. (2011). The history of development: from western origins to global faith (Third.). London: Zed Books.

Rosenbloom, A., \& Althaus, R. (2007). Reducing global poverty: Building the business case. International Journal of Interdisciplinary Social Sciences, 2(1), 417-423.

Sachs, I. (2004). Inclusive development and decent work for all. International Labour Review, 143(1-2), 161-173.

Sachs, W. (1990). The Archeology of the Development Idea. Interculture, 23(4).

Sahlins, M. (1992). The Economics of Develop-Man in the Pacific. Anthropology and Aesthetics, (21), 12-25. 
Sahlins, M. (1993). Cosmology of capitalism: the trans-pacific sector of the "World System." In N. Dicks, G. Eley, \& S. Orter (Eds.), Culture/power/history: A reader in contemporary social theory. Princeton: Princeton University Press.

Schumacher, E. F. (1973). Small is Beautiful. New York: Harper \& Row.

Schwittay, A. (2011). The Marketization of Poverty. Current Anthropology, 52, S71-S82.

Seelos, C., \& Mair, J. (2007). Profitable business models and market creation in the context of deep poverty: A strategic view. Academy of Management Perspectives, 21(4), 49-63.

Sengupta, A. (2010). Inclusive growth as rights-based development. Journal of Asian Public Policy, 3(3), 215-222.

Sesan, T., Raman, S., Clifford, M., \& Forbes, I. (2013). Corporate-Led Sustainable Development and Energy Poverty Alleviation at the Bottom of the Pyramid: The Case of the CleanCook in Nigeria. World Development, 45, 137-146.

Seyfang, G., \& Haxeltine, A. (2012). Growing grassroots innovations: exploring the role of community-based initiatives in governing sustainable energy transitions. Environment and Planning C: Governing and Policy, 30(3), 381-400.

Seyfang, G., \& Longhurst, N. (2013a). Desperately seeking niches: Grassroots innovations and niche development in the community currency field. Global Environmental Change, 23(5), 881-891.

Seyfang, G., \& Longhurst, N. (2013b). Growing green money? Mapping community currencies for sustainable development. Ecological Economics, 86, 65-77.

Seyfang, G., \& Smith, A. (2007). Grassroots innovations for sustainable development: Towards a new research and policy agenda. Environmental Politics, 16(4), 584-603.

Sharma, A., \& lyer, G. R. (2012). Resource-constrained product development: Implications for green marketing and green supply chains. Industrial Marketing Management, 41(4), 599_ 608.

Singh, R., Gupta, V., \& Mondal, A. (2012). Jugaad--From "Making Do" and "Quick Fix" to an Innovative, Sustainable and Low-Cost Survival Strategy at the Bottom of the Pyramid. International Journal of Rural Management, 8(1-2), 87-105.

Smith, A. (2005). The Alternative Technology Movement: An Analysis of its Framing and Negotiation of Technology Development. Human Ecology, 12(2), 106-119.

Smith, A. (2007). Translating Sustainabilities between Green Niches and Socio-Technical Regimes. Technology Analysis \& Strategic Management, 19(4), 427-450.

Smith, A., Arond, E., Fressoli, M., Thomas, H., \& Abrol, D. (2012). Supporting grassroots innovation: Facts and Figures - SciDev.Net.

Smith, A., Fressoli, M., \& Thomas, H. (2014). Grassroots innovation movements: challenges and contributions. Journal of Cleaner Production, 63, 114-124. 
Sonne, L. (2012). Innovative initiatives supporting inclusive innovation in India: Social business incubation and micro venture capital. Technological Forecasting and Social Change, 79(4), 638-647.

Srinivas, S., \& Sutz, J. (2008). Developing countries and innovation: Searching for a new analytical approach. Technology in Society, 30(2), 129-140.

Stirling, A. (2008). "Opening Up" and "Closing Down": Power, Participation, and Pluralism in the Social Appraisal of Technology. Science, Technology \& Human Values, 33(2), 262294.

Tarafdar, M., Anekal, P., \& Singh, R. (2012). Market development at the bottom of the pyramid: examining the role of information and communication technologies. Information Technology for Development, 18(4), 311-331.

Tarafdar, M., Singh, R., \& Anekal, P. (2013). Impact of ICT-enabled product and process innovations at the Bottom of the Pyramid: a market separations perspective. Journal of Information Technology, 28(4), 279-295.

The-economist. (2011). More than just digital quilting. The Economist.

Thomson, B. (2011). Pachakuti: Indigenous perspectives, buen vivir, sumaq kawsay and degrowth. Development, 54(4), 448-454.

UNDP. (2008). Creating Value for all: Strategies for Doing Business with the Poor. Retrieved from http://en.wikipedia.org/wiki/Inclusive_business_model

Van Griethuysen, P. (2010). Why are we growth-addicted? The hard way towards degrowth in the involutionary western development path. Journal of Cleaner Production, 18(6), 590-595.

Viswanathan, M., Yassine, A., \& Clarke, J. (2011). Sustainable Product and Market Development for Subsistence Marketplaces: Creating Educational Initiatives in Radically Different Contexts. Journal of Product Innovation Management, 28(4), 558-569.

Von Hippel, E. (2005). Democratizing Innovation. (E. Von Hippel, Ed.). Cambridge, Mass.: MIT Press.

Walsh, J. P., Kress, J. C., \& Beyerchen, K. W. (2005). Book review essay: Promises and perils at the bottom of the pyramid. Administrative Science Quarterly, 50(3), 473-482.

Weidner, K. L., Rosa, J. A., \& Viswanathan, M. (2010). Marketing to subsistence consumers: Lessons from practice. Journal of Business Research, 63(6), 559-569.

Weiss, M., Hoegl, M., \& Gibbert, M. (2011). Making Virtue of Necessity: The Role of Team Climate for Innovation in Resource-Constrained Innovation Projects. Journal of Product Innovation Management, 28, 196-207.

White, R., \& Stirling, A. (2013). Sustaining trajectories towards Sustainability: Dynamics and diversity in UK communal growing activities. Global Environmental Change, 23(5), 838846. 
White, S. C. (2010). Analysing wellbeing : a framework for development practice. Development in Practice, 20(2), 158-172.

Willmott, H. (2008). Critical management and global justice. Organization, 15(6), 927-931.

Wilson, G. (2007). Knowledge, innovation and re-inventing technical assistance for development. Progress in Development Studies, 7(3), 183-199.

World Bank. (2008). The Growth Report: Strategies for Sustained Growth and Inclusive Development. Washington, D.C: World Bank.

Zeschky, M., Widenmayer, B., \& Gassmann, O. (2011). Frugal Innovation in Emerging Markets: the Case of Mettler Toledo. Research-Technology Management, 54(4), 38-45. 